\title{
Molecular Marker Analysis of Soybean Plant Introductions with Resistance to Phytophthora sojae
}

\author{
S. G. Gordon, K. Kowitwanich, W. Pipatpongpinyo, S. K. St. Martin, and A. E. Dorrance
}

First, second, third and fifth authors: Department of Plant Pathology, The Ohio State University, Wooster, OH 44691; and fourth author: Department of Horticulture and Crop Science, The Ohio State University, Columbus, OH 43210.

Accepted for publication 11 August 2006.

\begin{abstract}
Gordon, S. G., Kowitwanich, K., Pipatpongpinyo, W., St. Martin, S. K., and Dorrance, A. E. 2007. Molecular marker analysis of soybean plant introductions with resistance to Phytophthora sojae. Phytopathology 97:113-118.

Molecular analysis of sources of resistance to plant pathogens should expedite and confirm novel gene discovery and consequently the development of disease resistant cultivars. Recently, soybean plant introductions (PIs) were identified that contain putative novel Rps genes for resistance to Phytophthora sojae. The number of resistance genes that confer resistance to $P$. sojae isolates $\mathrm{OH} 17(1 \mathrm{~b}, 1 \mathrm{~d}, 2,3 \mathrm{a}, 3 \mathrm{~b}, 3 \mathrm{c}, 4,5,6,7)$ and $\mathrm{OH} 25$

bean molecular linkage groups $\mathrm{F}, \mathrm{G}, \mathrm{J}$, and $\mathrm{N}$. Nine $\mathrm{F}_{2: 3}$ soybean populations were genotyped with simple sequence repeat (SSR) markers linked to previously mapped Rps loci. The nine PI populations all had SSR markers associated $(P<0.01)$ with resistance to $P$. sojae isolate $\mathrm{OH} 17$ in the $R p s 1$ region. Rps $1 \mathrm{c}$ is a likely candidate in eight PIs but novel genes may also be possible, while novel genes may confer resistance in one PI to $P$. sojae isolate $\mathrm{OHI}$. Two or more Rps genes, including some that are potentially novel, confer resistance to $P$. sojae isolate $\mathrm{OH} 25$ in eight of the populations. However, based on the response to these two isolates, virulence already exists for at least some of the novel genes identified in this study.
\end{abstract} $(1 \mathrm{a}, 1 \mathrm{~b}, 1 \mathrm{c}, 1 \mathrm{k}, 7)$ was then determined in several of the PIs. The objective of this study was to determine if the Rps genes present in these PIs were associated with eight described Rps loci that have been mapped on soy-
Additional keywords: Glycine max, host resistance.
Single, dominant R-genes to plant pathogens often occur in multigene clusters in many of the plant genomes that have been studied (23), including soybean (Glycine max L. Merr.) $(1,2,4,13,14,19,20,32)$. In rice (Oryza sativa L.) and Arabidopsis thaliana (L.) Heynh., whose entire genomes have been sequenced, these resistance gene clusters are made up of active Rgenes as well as numerous R-gene-like sequences (23). In soybean, these gene clusters consist of multiple R-genes that confer resistance to different pathogens, such as the Rps2 (resistance to Phytophthora sojae Kauf. and Gerd.) and Rmd (resistance to powdery mildew) loci on molecular linkage group (MLG) J (25); or to different isolates or strains of the same pathogen, such as the tightly linked loci that confer resistance to Soybean mosaic virus on MLG F (17).

Numerous resources now exist for soybean genetic analysis, including both classical and molecular markers as well as genetic linkage maps $(16,29)$. The most recent integrated genetic map of soybean is derived from five mapping populations and contains 20 linkage groups spanning more than $2,500 \mathrm{cM}$, defined by simple sequence repeat (SSR), restriction fragment length polymorphism (RFLP), random amplified DNA (RAPD), amplified fragment length polymorphism (AFLP), and classical markers $(24,29)$. These markers are an important resource for both basic and applied research, including investigations to characterize the resistance to soybean pathogens (18).

$P$. sojae causes root and stem rot of soybean, and is a welldescribed pathosystem (10). Fourteen resistance genes to $P$. sojae (Rps) have been described and mapped to eight loci in the soybean genome (Rps1 to Rps8) $(7,8,12,17)$ (Fig. 1). Rps 1 and Rps 7

Corresponding author: A. E. Dorrance; E-mail address: dorrance.1@osu.edu

DOI: 10.1094/PHYTO-97-0113

(C) 2007 The American Phytopathological Society are located on MLG N (22,31); Rps2 on MLG J (25); Rps3 and Rps8 on MLG F $(7,8,12)$; and Rps 4 and Rps6 on MLG G $(7,27)$. Current evidence suggests that Rps5 is located on MLG G and is linked to Rps4 $(7,8)$. Both Rps 1 and Rps 3 have multiple alleles (17).

Incorporation of Rps genes into soybean cultivars has been the primary strategy for managing Phytophthora root and stem rot $(3,17,28)$. Rps 1a was the first resistance gene to be widely deployed. It was first deployed during the 1960s and remained effective for approximately 8 years (28). Subsequently, Rps $1 \mathrm{c}$, $R p s 1 \mathrm{k}, R p s 3 \mathrm{a}$, and Rps 6 were deployed in the north central region of the United States, with Rps $1 \mathrm{k}$ remaining effective for almost 20 years (9). Thus, single gene-mediated resistance is an effective means for managing this soilborne disease; however, new genes that are effective against the current $P$. sojae populations are needed.

Dorrance and Schmitthenner (10) identified 32 plant introductions (PIs) that were proposed to contain novel Rps genes, combinations of novel and known Rps gene(s), or combinations of three known Rps loci. In a subsequent study (11), 12 of these PIs were crossed with the susceptible cv. Williams and were evaluated for segregation of resistance to two $P$. sojae isolates, OH17 (vir 1b, 1d, 2, 3a, 3b, 3c, 4, 5, 6, 7) and OH25 (vir 1a, 1b, $1 \mathrm{c}, 1 \mathrm{k}, 7)$, in the resulting populations. The two isolates used in this previous study were virulent to soybeans with all characterized Rps genes except Rps8 $(10,12)$. Based on the segregation data in the previous study, many of the PIs have two or more Rps loci, some of which appear to be novel. More specifically, resistance to $\mathrm{OH} 17$ was conferred by one locus in 12 populations and two loci in two populations. Resistance to $\mathrm{OH} 25$ was conferred by two loci in seven populations, by three loci in four populations, and by a single locus in one population (11).

These putatively novel Rps genes may be Rps 8 or novel alleles at known loci or new genes at loci where no Rps genes have been 
previously reported. There are other regions in the soybean genome where resistance genes exist to other pathogens, but to which no Rps genes have been mapped (19). Therefore, the objectives of this study were to determine if the Rps genes in these PIs were associated with previously described $R p s$ loci by genotyping with SSR markers linked to known Rps loci. For this study a subset of the PIs with specific phenotypic resistance responses to $P$. sojae isolates $\mathrm{OH} 17$ and $\mathrm{OH} 25$ were chosen (11). This strategy of phenotypic and genotypic analysis to identify associations to known Rps loci will provide insight as to which Rps genes may be present in these PIs. In addition, any lack of association with SSRs and Rps loci would then indicate that these PIs contain Rps genes at novel loci.

\section{MLG F}

MLG G

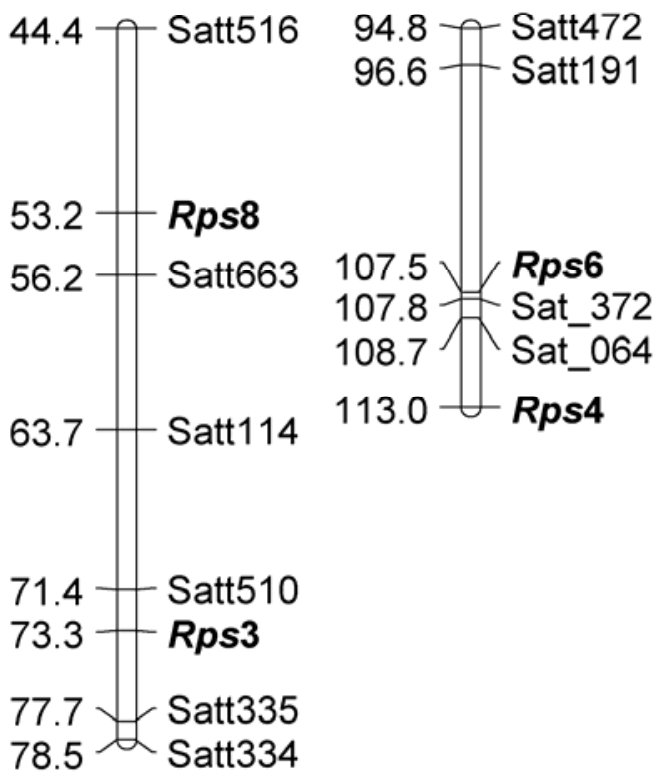

\section{MATERIALS AND METHODS}

Soybean populations and phenotypic data. Nine populations were selected for genotyping with SSRs based on population size and consistent segregation ratios for both $P$. sojae isolates between the $F_{2}$ and $F_{3}$ generations (Table 1). The resistance response to both isolates from the prior study was used in the molecular analyses.

The population development and phenotypic screen were described previously (11). Briefly, each PI was crossed with the susceptible cv. Williams and the $F_{1}$ and $F_{2}$ plants from each of these crosses were allowed to self-pollinate to produce populations of $\mathrm{F}_{2: 3}$ families. For phenotypic analysis, 10 to 20 soybean seedlings

\section{MLG J MLG N}

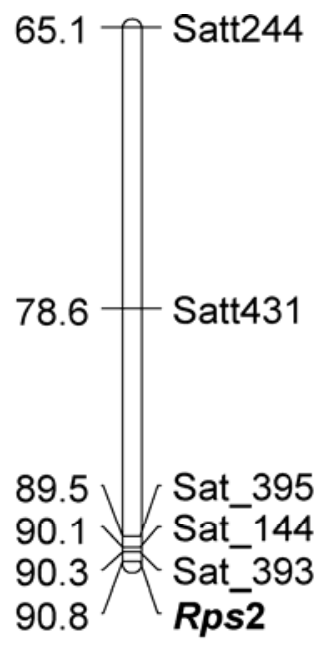

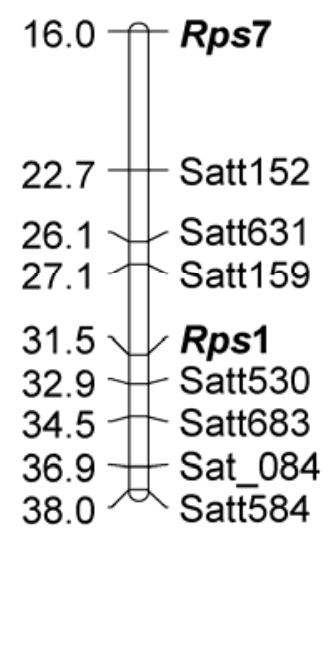

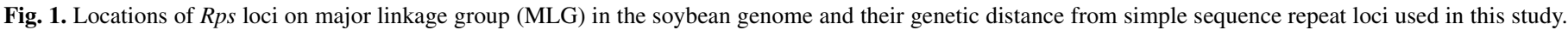
Distances are based on a merger of genetic maps from several reference soybean populations $(6,12,15,30)$.

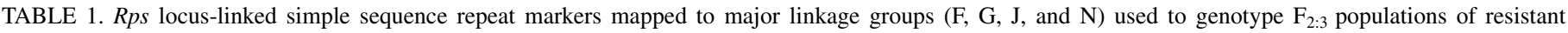
soybean plant introductions (PIs) crossed to the susceptible cv. Williams, and the number of families in each population

\begin{tabular}{|c|c|c|c|c|c|}
\hline Resistant parent & $\mathrm{F}_{2: 3}$ families & $\mathrm{F}(R p s 3,8)$ & $\mathrm{G}(R p s 4,6)$ & $\mathrm{J}(R p s 2)$ & $\mathrm{N}(R p s 1,7)$ \\
\hline PI273483D & 58 & $\begin{array}{l}\text { Satt510 } \\
\text { Satt663 }\end{array}$ & $\begin{array}{l}\text { Satt191 } \\
\text { Satt199 }\end{array}$ & $\begin{array}{l}\text { Satt244 } \\
\text { Satt287 } \\
\text { Satt431 }\end{array}$ & Satt152 \\
\hline PI398440 & 36 & $\begin{array}{l}\text { Satt510 } \\
\text { Satt114 }\end{array}$ & $\begin{array}{l}\text { Satt199 } \\
\text { Satt472 }\end{array}$ & $\begin{array}{l}\text { Sat_144 } \\
\text { Sat_393 }\end{array}$ & $\begin{array}{l}\text { Satt152 } \\
\text { Satt159 }\end{array}$ \\
\hline PI398694 & 75 & $\begin{array}{l}\text { Satt510 } \\
\text { Satt663 }\end{array}$ & $\begin{array}{l}\text { Satt191 } \\
\text { Satt199 }\end{array}$ & $\begin{array}{l}\text { Sat_144 } \\
\text { Sat_393 }\end{array}$ & Satt152 \\
\hline PI399036 & 92 & $\begin{array}{l}\text { Satt335 } \\
\text { Satt510 } \\
\text { Satt663 }\end{array}$ & $\begin{array}{l}\text { Sat_064 } \\
\text { Satt191 }\end{array}$ & $\begin{array}{l}\text { Sat_144 } \\
\text { Satt440 }\end{array}$ & $\begin{array}{l}\text { Satt631 } \\
\text { Satt683 }\end{array}$ \\
\hline PI399079 & 90 & $\begin{array}{l}\text { Satt334 } \\
\text { Satt114 }\end{array}$ & $\begin{array}{l}\text { Satt191 } \\
\text { Sat_372 }\end{array}$ & $\begin{array}{l}\text { Sat_395 } \\
\text { Satt440 }\end{array}$ & $\begin{array}{l}\text { Sat_084 } \\
\text { Satt152 }\end{array}$ \\
\hline PI407974B & 94 & $\begin{array}{l}\text { Satt510 } \\
\text { Satt516 }\end{array}$ & $\begin{array}{l}\text { Satt191 } \\
\text { Satt199 }\end{array}$ & Satt244 & Satt159 \\
\hline PI408097 & 93 & $\begin{array}{l}\text { Satt335 } \\
\text { Satt510 }\end{array}$ & $\begin{array}{l}\text { Satt472 } \\
\text { Satt199 }\end{array}$ & Satt431 & $\begin{array}{l}\text { Satt152 } \\
\text { Satt159 }\end{array}$ \\
\hline PI408211B & 93 & Satt510 & Satt191 & Satt215 & $\begin{array}{l}\text { Satt152 } \\
\text { Satt159 } \\
\text { Satt584 }\end{array}$ \\
\hline PI424354 & 92 & $\begin{array}{l}\text { Satt335 } \\
\text { Satt510 } \\
\text { Satt114 }\end{array}$ & Satt191 & $\begin{array}{l}\text { Satt440 } \\
\text { Sat_144 }\end{array}$ & $\begin{array}{l}\text { Satt159 } \\
\text { Satt631 } \\
\text { Satt683 }\end{array}$ \\
\hline
\end{tabular}


in each $\mathrm{F}_{2: 3}$ and $\mathrm{F}_{2: 4}$ family were inoculated with $P$. sojae isolates OH17 (vir 1b, 1d, 2, 3a, 3b, 3c, 4, 5, 6, 7) and OH25 (vir 1a, 1b, $1 \mathrm{c}, 1 \mathrm{k}, 7)$ by the hypocotyl method (12). Seedlings were scored as susceptible (expanding brown lesion) or resistant (necrotic lesion restricted to the inoculation site) 7 days following inoculation. Each family was then scored based on the percentage of susceptible responses as homozygous resistant(RR), 0 to $20 \%$; heterozygous ( $\mathrm{Rr}$ ), 21 to $79 \%$; or susceptible (rr), 80 to $100 \%$. This scoring was used to represent the $\mathrm{F}_{2}$ plant genotype. These data were then used to determine the number of Rps loci that conferred resistance to each $P$. sojae isolate (11).

SSR marker analysis. Tissue from 10 to 15 seedlings from each of the $\mathrm{F}_{2: 3}$ families was bulked, placed in liquid nitrogen, lyophilized, and ground for DNA extraction. DNA was extracted by a cetyltrimethylammoniumbromide method (26), yielding $500 \mu \mathrm{l}$ of sample with DNA concentrations ranging from 100 to $125 \mathrm{ng} / \mu \mathrm{l}$.

SSR markers were chosen from the integrated soybean genetic map $(6,30)$ based on their linkage $(3$ to $20 \mathrm{cM}$ ) to previously mapped Rps loci on MLGs F, G, J, and N (7,27,31) (Fig. 1). The SSR markers were screened for polymorphisms between the PIs and Williams, and those SSRs used to genotype each population are listed in Table 1. SSRs were amplified using standard polymerase chain reaction (PCR) protocols (16) with the exception that a touchdown PCR program was used to drop the annealing temperature 1 degree per cycle for eight cycles, from $58^{\circ}$ to $50^{\circ} \mathrm{C}$, and then 30 cycles were run with an annealing temperature of $50^{\circ} \mathrm{C}$.

Single factor analyses using the $P$. sojae resistance response for each isolate as the dependent variable were completed for each marker in each population using SAS PROC GLM (SAS Institute, Cary, NC). The model was $y_{\mathrm{ij}}=\mu+\alpha_{i}+\mathrm{e}_{\mathrm{ij}}$ where $y_{\mathrm{ij}}$ is the trait value of the $j$ th genotype of the $i$ th marker class, $\mu$ is the population mean, $\alpha_{i}$ is the effect of the $i$ th marker class, and $e_{i j}$ is the experimental error.

Power analysis. For an R-gene phenotype analysis, the expression of one R-gene will partially mask the presence of the second when they are both effective against a specific isolate. In order to determine the statistical power to detect associations between SSRs and phenotypic response to $P$. sojae governed by multiple Rps loci, and therefore minimize both type I (false negative) and type II (false positive) error, a power analysis was performed (21). Power is the probability of detecting linkage (by obtaining a significant result that rejects the null hypothesis of independent assortment), given that linkage of a given intensity exists and a population of a given size is sampled.

Power to detect association between SSRs and Rps loci was estimated using a 1-tailed $\mathrm{z}$ test at alpha $=0.05$ for a binomial frequency, based on the relative frequencies of the phenotypic classes most sensitive to linkage, i.e., the combined frequency of resistant $(\mathrm{MM})$ and heterogeneous $(\mathrm{Mm})$ classes versus that of the resistant (MM) and heterogeneous (Mm) classes (21). If MM, $\mathrm{Mm}$, and $\mathrm{mm}$ are the three genotypic classes of the SSR marker and resistant $(\mathrm{R})$, heterozygous $(\mathrm{H})$, and susceptible $(\mathrm{S})$ are the three phenotypic classes of the resistance assay, then the classes $(\mathrm{MM}+\mathrm{R})$ and $(\mathrm{Mm}+\mathrm{H})$ represent combinations of one recombinant and one parental (nonrecombinant) gamete, and $(\mathrm{MM}+\mathrm{H})$ and $(\mathrm{Mm}+\mathrm{R})$ represent combinations of recombinant gametes. The relative proportions of $(\mathrm{MM}+\mathrm{R})+(\mathrm{Mm}+\mathrm{H})$ and of $(\mathrm{MM}+\mathrm{H})$ $+(\mathrm{Mm}+\mathrm{R})$ are very sensitive to linkage. Let $\mathrm{p}=[(\mathrm{MM}+\mathrm{R})+$ $(\mathrm{Mm}+\mathrm{H})] /[(\mathrm{MM}+\mathrm{R})+(\mathrm{Mm}+\mathrm{H})+(\mathrm{MM}+\mathrm{H})+(\mathrm{Mm}+\mathrm{R})]$. Then, for example, when there is no linkage, $\mathrm{p}=0.511$. (This is shown by making the Punnett square and performing the necessary algebra.)

If complete linkage between $\mathrm{M} / \mathrm{m}$ and $\mathrm{R} / \mathrm{r}$ is present, then $\mathrm{p}=0.833$. If the two loci are $10 \mathrm{~cm}$ apart, then $\mathrm{p}=0.738$, and so on. The binomial test of linkage is a test of the null hypothesis that $\mathrm{p}=0.511$ (no linkage) against the alternative hypothesis that $\mathrm{p}>0.511$ (linkage). This test included only those individuals from the assay that fell into the four classes $(\mathrm{MM}+\mathrm{R}, \mathrm{Mm}+\mathrm{H}, \mathrm{MM}+\mathrm{H}$, and $\mathrm{Mm}+\mathrm{R}$ ) that collectively make up approximately $70 \%$ of the population. The null hypothesis was rejected when the observed ratio $\left(\mathrm{p}^{\wedge}\right)$ falls in the rejection region. The rejection region consists of the right tail $(5 \%)$ of the distribution and lies above 0.511 . Given the population size and the true value of $p, 0.738$, for example, the power of the binomial test equals the probability that $\mathrm{p}^{\wedge}$ falls in the rejection region.

Example of calculations. For $100 \mathrm{~F}_{2}$ lines, the number falling in the four pertinent classes is expected to be 70 . The rejection region can be calculated as any $\mathrm{p}^{\wedge}$ exceeding 0.609 . If linkage exists at $10 \mathrm{cM}$, the expected value of $\mathrm{p}$ is 0.738 , as mentioned above. The probability is .99 that a sample of 70 individuals will give a $\mathrm{p}^{\wedge}$ greater than 0.609 if the true value of $\mathrm{p}$ is 0.738 , i.e., that is the power of the test in that situation. Calculation of the rejection region and the power is done by using a normal approximation to the binomial distribution.

\section{RESULTS AND DISCUSSION}

The statistical power analysis was completed for one-, two-, and three-locus models and a theoretical population size of $94 \mathrm{~F}_{2}$ families, and for a single-locus model in a population size of 50 families (Table 2). For the larger population of $94 \mathrm{~F}_{2}$ families, the power analysis indicates that for genetic distances of $15 \mathrm{cM}$ or less between Rps and SSR loci, there was greater than $90 \%$ probability of detecting a statistical association for a particular SSR when either one or two segregating Rps loci were present (Table 2). For a distance of $20 \mathrm{cM}$, there was greater than $80 \%$ probability of detecting a statistical association between an SSR and an $R p s$ locus. For the three-Rps locus model there was greater than $90 \%$ probability of detecting an association at a distance of $10 \mathrm{cM}$, greater than $79 \%$ probability of detecting an association at a distance of $15 \mathrm{cM}$, and greater than $62 \%$ probability of detecting an association at $20 \mathrm{cM}$ (Table 2). These calculations, since they are based on a relatively crude test for linkage, probably underestimate the power of the statistical analysis that was used in this study. In addition, the test is based on a single SSR marker. For most of the populations, there was more than one marker per Rps locus (Table 1), and in these situations the power to detect associations with at least one marker is greater than the results of the power analysis.

In the first study (10) these PIs were identified based on their resistance to a number of $P$. sojae isolates whose combined virulence specificities encompassed soybeans with all known Rps

TABLE 2. Statistical power ${ }^{a}$ to detect association of simple sequence repeat (SSR) markers with Rps loci responsible for resistance to Phytophthora sojae isolates $\mathrm{OH} 17$ and $\mathrm{OH} 25$

\begin{tabular}{lcccc}
\hline $\begin{array}{l}\text { Recombination } \\
\text { frequency }\end{array}$ & 1 gene $^{\mathrm{b}}$ & 2 genes $^{\mathrm{b}}$ & 3 genes $^{\mathrm{b}}$ & 1 gene $^{\mathrm{c}}$ \\
\hline 0 & 1.00 & 1.00 & 0.99 & 1.00 \\
0.05 & 1.00 & 0.99 & 0.98 & 0.98 \\
0.10 & 1.00 & 0.99 & 0.92 & 0.90 \\
0.15 & 0.99 & 0.95 & 0.79 & 0.75 \\
0.20 & 0.93 & 0.81 & 0.62 & 0.57 \\
0.25 & 0.73 & 0.60 & 0.45 & $\ldots$ \\
0.30 & 0.46 & 0.39 & 0.30 & $\ldots$ \\
0.35 & 0.25 & 0.24 & 0.20 & $\ldots$ \\
0.40 & 0.13 & 0.14 & 0.13 & $\ldots$ \\
0.45 & 0.07 & 0.08 & 0.09 & $\ldots$
\end{tabular}

a Power was calculated for one-, two-, and three-Rps locus models in a population of $94 \mathrm{~F}_{2: 3}$ families and for a one-Rps locus model in a population of $50 \mathrm{~F}_{2: 3}$ families. Probability is the likelihood of detecting linkage at a given recombination frequency between Rps and SSR loci at alpha $=0.05$.

b Power to detect associations in a population of 94 families.

c Power to detect associations in a population of 50 families. 


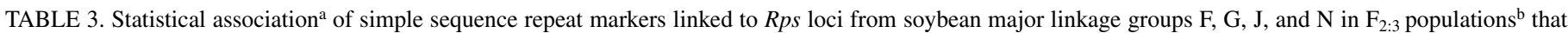

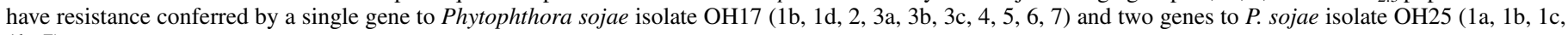
$1 \mathrm{k}, 7)$

\begin{tabular}{|c|c|c|c|c|c|c|}
\hline Resistant parent & Number of families & P. sojae isolate & $\mathrm{F}(R p s 3,8)$ & $\mathrm{G}(R p s 4,6)$ & $\mathrm{J}(R p s 2)$ & $\mathrm{N}(R p s 1,7)$ \\
\hline \multirow[t]{2}{*}{ PI273483D } & 58 & OH17 & ns & ns & $*$ & $* * *$ \\
\hline & & $\mathrm{OH} 25$ & ns & ns & ns & ns \\
\hline \multirow[t]{2}{*}{ PI398694 } & 75 & OH17 & ns & $\mathrm{ns}$ & ns & $* * *$ \\
\hline & & $\mathrm{OH} 25$ & $\mathrm{~ns}$ & $* *$ & ns & ns \\
\hline \multirow[t]{2}{*}{ PI407974B } & 94 & OH17 & $\mathrm{ns}$ & $\mathrm{ns}$ & ns & $* * *$ \\
\hline & & $\mathrm{OH} 25$ & ns & $* * *$ & ns & ns \\
\hline \multirow[t]{2}{*}{ PI408097 } & 93 & OH17 & ns & ns & ns & $* * *$ \\
\hline & & $\mathrm{OH} 25$ & $*$ & $* * *$ & ns & ns \\
\hline
\end{tabular}

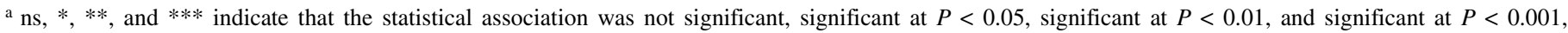
respectively.

${ }^{\mathrm{b}}$ Populations of segregating $\mathrm{F}_{2: 3}$ families were developed from crosses of resistant PI with susceptible cv. Williams.

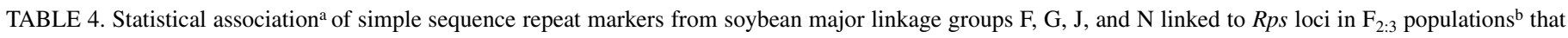

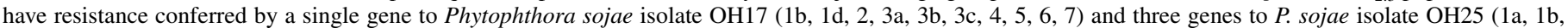
$1 \mathrm{c}, 1 \mathrm{k}, 7)$

\begin{tabular}{|c|c|c|c|c|c|c|}
\hline Resistant parent & Number of families & P. sojae isolate & $\mathrm{F}(\operatorname{Rps} 3,8)$ & $\mathrm{G}(\operatorname{Rps} 4,6)$ & $\mathrm{J}(R p s 2)$ & $\mathrm{N}(R p s 1,7)$ \\
\hline \multirow[t]{2}{*}{ PI399036 } & 92 & $\mathrm{OH} 17$ & ns & $*$ & ns & $* * *$ \\
\hline & & $\mathrm{OH} 25$ & ns & $* * *$ & ns & ns \\
\hline \multirow[t]{2}{*}{ PI408211B } & 93 & $\mathrm{OH} 17$ & ns & ns & ns & $* * *$ \\
\hline & & $\mathrm{OH} 25$ & ns & ns & ns & $*$ \\
\hline
\end{tabular}

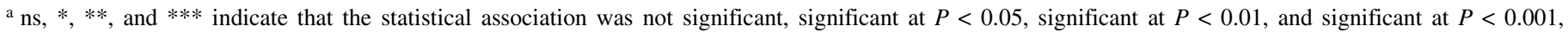
respectively.

${ }^{\mathrm{b}}$ Populations of segregating $\mathrm{F}_{2: 3}$ families were developed from crosses of resistant plant introductions (PIs) with susceptible cv. Williams.

genes and two-gene combinations as well as most three-gene combinations with the exception of the gene combination(s) of Rps 1c, 2, 3 (a or b), and 4. Therefore, the primary hypothesis was that these PIs contain a combination of $\operatorname{Rps} 1 \mathrm{c}, 2,3$ (a or b), 4, or novel gene(s) plus known Rps genes. Based on phenotypic analysis, resistance to $\mathrm{OH} 17$ and $\mathrm{OH} 25$ was conferred by one and two loci, respectively, in PI273483D, PI398694, PI407974B, and PI408097. SSRs linked to Rps 1 and $R p s 7$ on MLG N were associated $(P<0.001)$ with resistance to $\mathrm{OH} 17$ for all four PIs (Table 3). Of these four PIs, only one was identified with markers significantly associated with resistance at two loci for $\mathrm{OH} 25$. None of the Rps loci were associated with resistance to $\mathrm{OH} 25$ in PI273483D with a moderate population size of 50 families. Resistance to OH25 in PI398694, PI407974B, and PI408097 was associated with SSRs linked to Rps 4 or Rps6 $(P<0.001)$ (Table 3). $P$. sojae isolate $\mathrm{OH} 25$ has avirulence to soybeans with both Rps4 and Rps6; therefore one of these two linked loci is likely the resistance locus. SSRs were associated $(P<0.05)$ with resistance to $\mathrm{OH} 25$ at the Rps3 and Rps8 loci in PI408097 (Table 3). Even though resistance to $\mathrm{OH} 17$ was conferred by one locus, one PI had SSRs at additional loci associated with resistance to this isolate $(P=0.05)$ : PI273483D with SSRs linked to Rps2. For PI273483D and PI399036, more resistance loci were detected than predicted by the segregation ratio to $\mathrm{OH} 17$, which was $3: 1$. The $P$ values for the additional SSR loci associated with resistance were marginally significant $(P=0.01$ to 0.05$)$; these results could also be false positives. All of the associations between SSR markers and $P$. sojae resistance, while convincing, are statistical functions and must be further scrutinized. Further experiments are in progress, including genetic mapping in advanced generations, to confirm the proposed novel Rps loci, and to develop populations for allelism tests. Only PI408097 fit the proposed model of Rps gene combinations (Rps 1c, 2, 3 [a or b], and 4) based on the genotypic evaluations. Resistance to OH17 was associated with MLG N where Rps 1 mapped, thus indicating that Rpslc may be involved and that resistance to $\mathrm{OH} 25$ was linked to MLGs F (Rps3) and G (Rps4, PI408097).
In two PI populations (PI399036 and PI408211B) where a single locus conferred resistance to $\mathrm{OH} 17$ and three loci conferred resistance to $\mathrm{OH} 25$, SSRs linked to Rps 1 and Rps 7 on MLG N were associated with resistance to $\mathrm{OH} 17(P<0.001)$ (Table 4$)$. Resistance to OH25 in PI399036 was associated with SSRs linked to Rps 4 or Rps6 on MLG G (Table 4) but no significant associations were detected for the remaining two loci. Resistance to $\mathrm{OH} 25$ in PI408211B was linked to Rps 1 on MLG N (Table 4) which suggests the presence of a novel gene on MLG $\mathrm{N}$ in PI408211B. This is very strong evidence for a novel gene as none of the previously described Rps genes in the Rps 1 locus confer resistance to both $\mathrm{OH} 17$ and $\mathrm{OH} 25$.

Resistance to $P$. sojae isolates $\mathrm{OH} 17$ and $\mathrm{OH} 25$ was conferred by a single locus in PI398440. However, in the previous study the $\mathrm{F}_{2: 3}$ families did not respond consistently to both isolates; some families that were resistant to $\mathrm{OH} 17$ were susceptible to $\mathrm{OH} 25$ or vice versa (11). For PI398440, only SSRs linked to Rps 1 and Rps 7 on MLG N were associated with resistance to $\mathrm{OH} 17$ $(P<0.001)$, while no SSRs were associated with resistance to $\mathrm{OH} 25$ (Table 5). These results suggest that resistance to $\mathrm{OH} 25$ in PI398440 may reside at a novel locus. This genotypic evaluation confirms that different regions of the genome confer resistance to each isolate. This is not only strong evidence for novel genes in these populations but for novel virulence in the $P$. sojae isolates as well. The virulence that exists in $\mathrm{OH} 17$ and $\mathrm{OH} 25$ to soybeans with these novel Rps genes may prevent them from being useful for management of Phytophthora root and stem rot.

Two loci conferred resistance to OH17 in PI399079 and PI424354 (11). In both of these populations, SSRs linked to Rps 1 and Rps 7 were associated with resistance $(P<0.001)$ (Table 6). No additional SSRs were associated with resistance to $\mathrm{OH} 17$ in PI399079, while SSRs linked to Rps3 or Rps 8 were identified in PI424354. Resistance to $\mathrm{OH} 25$ was associated with SSRs linked to Rps4/Rps6 on MLG G in the PI424354 population $(P<0.001)$; no SSRs were associated with resistance for PI399079. These results indicate that these PIs may contain a novel locus. OH17 has virulence for genes at all of the described Rps loci except for 
TABLE 5. Statistical association ${ }^{\mathrm{a}}$ of simple sequence repeat markers from soybean major linkage groups $\mathrm{F}, \mathrm{G}, \mathrm{J}$, and $\mathrm{N}$ linked to Rps loci in $\mathrm{F}_{2: 3}$ population ${ }^{\mathrm{b}}$ of Williams by plant introduction (PI) 398440 that has resistance conferred by a single gene to both Phytophthora sojae isolates OH17 (1b, 1d, 2, 3a, 3b, 3c, 4, 5, 6, 7) and $\mathrm{OH} 25(1 \mathrm{a}, 1 \mathrm{~b}, 1 \mathrm{c}, 1 \mathrm{k}, 7)$

\begin{tabular}{lcccccc}
\hline Resistant parent & Number of families & P. sojae isolate & $\mathrm{F}($ Rps3,8) & $\mathrm{G}($ Rps 4,6$)$ & $\mathrm{J}($ Rps2) & $\mathrm{N}($ Rps 1,7$)$ \\
\hline PI398440 & \multirow{2}{*}{36} & OH17 & $\mathrm{ns}$ & $\mathrm{ns}$ & $\mathrm{ns}$ & $* * *$ \\
& & OH25 & $\mathrm{ns}$ & $\mathrm{ns}$ & $\mathrm{ns}$ & $\mathrm{ns}$ \\
\hline
\end{tabular}

a ns, *,**, and *** indicate that the statistical association was not significant, significant at $P<0.05$, significant at $P<0.01$, and significant at $P<0.001$, respectively.

b Populations of segregating $\mathrm{F}_{2: 3}$ families were developed from crosses of resistant PI with susceptible cv. Williams.

TABLE 6. Statistical association ${ }^{\mathrm{a}}$ of simple sequence repeat markers from soybean major linkage groups $\mathrm{F}, \mathrm{G}, \mathrm{J}$, and $\mathrm{N}$ linked to Rps loci in $\mathrm{F}_{2: 3}$ populations $\mathrm{s}^{\mathrm{b}}$ that have resistance conferred by two genes to Phytophthora sojae isolate OH17 (1b, 1d, 2, 3a, 3b, 3c, 4, 5, 6, 7) and either two (424234B) or three genes (424354) to P. sojae isolate $\mathrm{OH} 25(1 \mathrm{a}, 1 \mathrm{~b}, 1 \mathrm{c}, 1 \mathrm{k}, 7)$

\begin{tabular}{lcccccc}
\hline Resistant parent & Number of families & P. sojae isolate & $\mathrm{F}($ Rps3,8) & $\mathrm{G}($ Rps 4, 6) & $\mathrm{J}($ Rps2) & $\mathrm{N}($ Rps 1,7$)$ \\
\hline PI399079 & 90 & OH17 & $\mathrm{ns}$ & $\mathrm{ns}$ & $\mathrm{ns}$ & $* * *$ \\
& & OH25 & $\mathrm{ns}$ & $\mathrm{ns}$ & $\mathrm{ns}$ & $\mathrm{ns}$ \\
PI424354 & 92 & OH17 & $*$ & $\mathrm{~ns}$ & $\mathrm{~ns}$ & $\mathrm{~ns}$ \\
& & OH25 & $\mathrm{ns}$ & $* * *$ & $\mathrm{~ns}$ \\
\hline
\end{tabular}

a ns, *,**, and *** indicate that the statistical association was not significant, significant at $P<0.05$, significant at $P<0.01$, and significant at $P<0.001$, respectively.

${ }^{b}$ Populations of segregating $\mathrm{F}_{2: 3}$ families were developed from crosses of resistant plant introductions (PIs) with susceptible cv. Williams.

Rps 1 alleles 1a, 1c, and 1k. Thus, the second gene conferring resistance is indeed novel. Of most interest is the locus in PI399079, in which only SSRs linked to a single known Rps locus were associated with resistance to $\mathrm{OH} 17$. In addition, the lack of association for the second locus and for $\mathrm{OH} 25$ also indicate that this population has the higher probability of identifying another region in the soybean genome where the second Rps locus resides.

The PIs used as the resistant parents in this study originated primarily from South Korea. Burnham et al. (5) evaluated the genetic diversity of these PIs and concluded that they are genetically distant from U.S. and Chinese genotypes based on SSR analysis. In addition to being sources of $P$. sojae resistance, these PIs have the potential to broaden the genetic diversity of U.S. soybean germ plasm. Using chi-square analysis of SSR allele frequencies, Burnham et al. (5) also found that MLG A2 SSRs were significantly associated with resistant PIs but not with susceptible PIs. In the current study three populations were genotyped with MLG A2 SSRs and no association with $P$. sojae resistance was found (data not shown).

In summary, this study confirms the existence of multiple Rps loci in these soybean PIs, including some that are potentially novel. These potentially novel loci fall into two categories: novel alleles of known loci and putatively new genes at new loci. While all these PIs are resistant to $P$. sojae isolates $\mathrm{OH} 17$ and $\mathrm{OH} 25$, it is clear from the results that the resistance is quite diverse in its genetic basis. In addition to novel resistance loci, these data demonstrate the existence of undescribed virulence genes in $P$. sojae which also require further characterization. The usefulness of these PIs for management of Phytophthora root and stem rot will ultimately depend on the proportion of the $P$. sojae population to which these genes confer resistance.

\section{ACKNOWLEDGMENTS}

We thank R. Fioritto, S. McIntyre, G. Mills, and B. Sugerman for development of plant populations; S. A. Berry, A. Mills, and K. Burnham for plant inoculations; and B. Bishop for assistance with data analysis. This project was sponsored by Ohio's soybean producers' check-off dollars through the Ohio Soybean Council. Salaries and research support were provided by state and federal funds appropriated to the Ohio Agricultural Research and Development Center, The Ohio State University, Wooster, $\mathrm{OH}$.

\section{LITERATURE CITED}

1. Anderson, T. R., and Buzzell, R. I. 1992. Inheritance and linkage of the Rps 7 gene for resistance to Phytophthora rot of soybean. Plant Dis. 76:958-959.

2. Ashfield, T., Danzer, J. R., Held, D., Clayton, K., Keim, P., SaghaiMaroof, M. A., Webb, D. M., and Innes, R. W. 1998. Rpg1, a soybean gene effective against races of bacterial blight, maps to a cluster of previously identified disease resistance genes. Theor. Appl. Genet. 96:1013-1021.

3. Athow, K. L. 1985. Phytophthora root rot of soybean. Pages 575-581 in: Proc. World Soybean Res. Con. III. R. Shibles, ed. Westview Press, Boulder, $\mathrm{CO}$.

4. Bhattacharyya, M. K., Narayanan, N. N., Gao, H., Santra, D. K., Salimath, S. S., Kasuga, T., Liu, Y., Espinosa, B., Ellison, L., Marek, L., Shoemaker, R., Gijzen, M., and Buzzell, R. I. 2005. Identification of a large cluster of coiled coil-nucleotide binding site-leucine rich repeat-type genes from the Rps 1 region containing Phytophthora resistance genes in soybean. Theor. Appl. Genet. 111:75-86.

5. Burnham, K. D., Francis, D. M., Dorrance, A. E., Fioritto, R. J., and St. Martin, S. K. 2002. Genetic diversity patterns among Phytophthora resistant soybean plant introductions based on SSR markers. Crop Sci. 42:338-343.

6. Cregan, P. B., Jarvik, T., Bush, A. L., Shoemaker, R. C., Lark, K. G., Kahler, A. L., Kaya, N., VanToai, T. T., Lohnes, D. G., Chung, J., and Specht, J. E. 1999. An integrated genetic linkage map of the soybean genome. Crop Sci. 39:1464-1490.

7. Demirbas, A., Rector, B. G., Lohnes, D. G., Fioritto, R. J., Graef, G. L., Cregan, P. B., Shoemaker, R. C., and Specht, J. E. 2001. Simple sequence repeat markers linked to the soybean Rps genes for Phytophthora resistance. Crop Sci. 41:1220-1227.

8. Diers, B. W., Mansur, L., Imsande, J., and Shoemaker, R. C. 1992. Mapping Phytophthora resistance loci in soybean with restriction fragment polymorphism markers. Crop Sci. 32:377-383.

9. Dorrance, A. E., McClure, S. A., and de Silva, A. 2003. Pathogenic diversity of Phytophthora sojae in Ohio soybean fields. Plant Dis. 87:139146.

10. Dorrance, A. E., and Schmitthenner, A. F. 2000. New sources of resistance to Phytophthora sojae in the soybean plant introductions. Plant Dis. 84:1303-1308.

11. Gordon, S. G., Kowitwanich, K., Pipatpongpinyo, W., St. Martin, S. K., and Dorrance, A. E. 2007. Genetic analysis of soybean plant introduction with resistance to Phytophthora sojae. Phytopathology 97:113-118.

12. Gordon, S. G., St. Martin, S. K., and Dorrance, A. E. 2004. Mapping $R p s 8$, a gene for resistance to Phytophthora root and stem rot in soybean. Page 320 in: Crop Sci. Soc. America Annu. Mtg., ASA-CSA-SS, Madison, WI.

13. Graham, M. A., Marek, L. F., Lohnes, D., Cregan, P., and Shoemaker, R. C. 2000. Expression and genome organization of resistance gene analogs in soybean. Genome 43:86-93. 
14. Graham, M. A., Marek, L. F., and Shoemaker, R. C. 2002. PCR sampling of disease resistance-like sequences from a disease resistance gene cluster in soybean. Theor. Appl. Genet. 105:50-57.

15. Grant, D., Imsande, M. I., and Shoemaker, R. C. 2002. Soybase; The USDA-ARS Soybean Genome Database. Published online by USDA-ARS.

16. Grau, C. R., Dorrance, A. E., Bond, J., and Russin, J. 2004. Fungaldiseases. Pages 679-763 in: Soybeans: Improvement, Production, andUses. 3rd ed. H. R. Boerma and J. E. Specht, eds. Agron. Monogr. 16. ASA, CSSA, and SSSA, Madison, WI.

17. Hayes, A. J., Jeong, S. C., Gore, M. A., Yu, Y. G., Buss, G. R., Tolin, S. A., and Saghai-Maroof, M. A. 2004. Recombination within a nucleotidebinding-site/leucine-rich-repeat gene cluster produces new variants conditioning resistance to Soybean mosaic virus in soybeans. Genetics 166:493-503

18. Hegstad, J. M., Nickell, C. D., and Vodkin, L. O. 1998. Identifying resistance to Phytophthora sojae in selected soybean accessions using RFLP techniques. Crop Sci. 38:50-55.

19. Kanazin, V., Marek, L. F., and Shoemaker, R. C. 1996. Resistance gene analogs are conserved and clustered in soybean. Proc. Natl. Acad. Sci. USA 93:11746-11750.

20. Lewers, K., Heinz, R., Beard, H., Marek, L., and Matthews, B. 2002. A physical map of a gene-dense region in soybean linkage group A2 near the black seed coat and Rhg4 loci. Theor. Appl. Genet. 104:254-260.

21. Liu, B. 1998. Statistical Genomics. CRC Press, NY.

22. Lohnes, D. G., and Schmitthenner, A. F. 1997. Position of the Phytophthora resistance gene Rps 7 on the soybean molecular map. Crop Sci. 37:555-556

23. Meyers, B. C., Kaushik, S., and Nandety, R. S. 2005. Evolving disease resistance genes. Curr. Opin. Plant Biol. 8:129-134.

24. Palmer, R. G., Pfeiffer, T. W., Buss, G. R., and Kilen, T. C. 2004.
Qualitative genetics. Pages 679-763 in: Soybeans: Improvement, Production, and Uses. 3rd ed. H. R. Boerma and J. E. Specht, eds. Agron. Monogr. 16. ASA, CSSA, and SSSA, Madison, WI.

25. Polzin, K. M., Lohnes, D. G., Nickell, C. D., and Shoemaker, R. C. 1994. Integration of $R p s 2, R m d$, and $R j 2$ in linkage group $\mathrm{J}$ of the soybean molecular map. J. Hered. 85:300-303.

26. Saghai-Maroof, M. A., Soliman, K. M., Jorgensen, R. A., and Allard, R. W. 1984. Ribosomal DNA spacer-length polymorphisms in barley: Mendelian inheritance, chromosomal location, and population dynamics. Proc. Natl. Acad. Sci. USA 81:8014-8018.

27. Sandhu, D., Gao, H., Cianzio, S., and Battacharyya, M. K. 2004. Deletion of a disease resistance nucleotide-binding-site leucine-rich-repeat-like sequence is associated with the loss of Phytophthora resistance gene Rps 4 in soybean. Genetics 168:2157-2167.

28. Schmitthenner, A. F. 1985. Problems and progress in control of Phytophthora root rot of soybean. Plant Dis. 69:362-368.

29. Shoemaker, R. C., Cregan, P. B., and Vodkin, L. O. 2004. Soybean genomics. Pages 235-263 in: Soybeans: Improvement, Production, and Uses. 3rd ed. H. R. Boerma and J. E. Specht, eds. Agron. Monogr. 16. ASA, CSSA, and SSSA, Madison, WI.

30. Song, Q. J., Marek, L. F., Shoemaker, R. C., Lark, K. G., Concibido, V. C., Delannay, X., Specht, J. E., and Cregan, P. B. 2004. A new integrated genetic linkage map of the soybean. Theor. Appl. Genet. 109:121-128.

31. Weng, C., Yu, K., Anderson, T. R., and Poysa, V. 2001. Mapping genes conferring resistance to Phytophthora root rot of soybean, Rps 1a and Rps7. J. Hered. 92:442-446.

32. Yu, Y. G., Buss, G. R., and Saghai-Maroof, M. A. 1996. Isolation of a superfamily of candidate disease-resistance genes in soybean based on a conserved nucleotide-binding site. Proc. Natl. Acad. Sci. USA 93:1175111756. 